\title{
Attitudes of Czech pupils who are deaf or hard of hearing towards physical education classes: A comparison of gender differences
}

\author{
Petra Kurková* \\ Faculty of Education, Palacký University Olomouc, Olomouc, Czech Republic
}

Copyright: (C) 2018 P. Kurková. This is an open access article licensed under the Creative Commons Attribution License (http://creativecommons.org/licenses/by/4.0/).

Background: Physical education is an organised form of physical activity and can be viewed as an interaction between the ideas of difficulty and importance that are gradually developed by both the teacher and the pupil. Objective: The objective of this study was to analyse differences in pupils' attitudes by gender in the second stage of primary schools for the deaf or hard of hearing in physical education classes. Methods: Participants were 86 pupils who are deaf or hard of hearing (boys, $n=56 ; 65.1 \%$; girls, $n=30 ; 34.9 \%$ ). The mean age and standard deviation was $14.3 \pm 1.4$ years. The data were described using absolute and relative frequencies, including the mean and standard deviation. The non-parametric Mann-Whitney $U$-test was used to assess differences between two independent groups (boys versus girls). For calculation of effect size coefficient abs $(r)$ was used. All tests were performed at a level of $\alpha=.05$. Results: In physical education classes, statistically significant differences were found in the effort made, with boys making more effort in physical education classes than girls $(Z=-2.048 ; p=.041 ; \operatorname{abs}(r)=.221)$. For the other indicators under review, no differences were found. Conclusion: Both boys and girls consider physical education to be their favourite subject, it makes them feel good, and there are no major differences in their emotional response. However, boys make much more effort in physical education classes.

Keywords: emotions, feelings, popularity, importance, demandingness, effort

\section{Introduction}

In the Czech Republic, education in primary schools is spread over nine years and is divided into the first stage (years 1 to 5 ) and the second stage (years 6 to 9). All primary schools for the deaf or hard of hearing take advantage of Section 46(3) of the Education Act (2004), which makes it possible to extend school attendance to ten years, upon approval from the ministry. In such a case, the first stage comprises years 1 to 6 and the second stage comprises years 7 to 10 . The advantage of primary schools for the deaf or hard of hearing is a good didactic quality of teaching, which is appropriate to the pupils' abilities. Another advantage may also be the very good organisation of free time in these facilities, with a focus on the specific aspects of communication within this minority population (Kurková \& Scheetz, 2016; Kurková, Scheetz, \& Stelzer, 2010).

\footnotetext{
* Address for correspondence: Petra Kurková, Department of Anthropology and Health Education, Faculty of Education, Palacký University Olomouc, Žižkovo nám. 5, 77140 Olomouc, Czech Republic. E-mail: petra.kurkova@upol.cz
}

The disadvantage of this type of education may be the boarding-school nature of education, which removes the child from the natural family environment from an early age, severs ties to the family, minimizes opportunities to gain common experience, and education is isolated from real life (Scheetz, 2012).

Physical education is an organised form of physical activity. Within the Framework Educational Programme for Basic Education (FEP), the 'Physical Education' educational field is included in the 'People and Health' educational area. It aims to give an understanding of one's own physical capabilities and the effects of physical activities on physical fitness as well as mental and social well-being. The FEP (2016) describes the purpose of physical education as "the ability to independently assess the level of one's own fitness and to physical activity in the daily activity pattern in order to satisfy one's own physical needs and interests, achieve optimal development of fitness and performance, regenerate strength and compensate for various types of strain and stress, and promote health and protect life" (p. 91). As well as for mainstream 
pupils is Physical Education for pupils for the deaf or hard of hearing required for the second stage two hours per week.

As far back as 30 years ago, Antonak and Livneh (1988) found out that nearly 500 definitions of the terms attitude were published. Attitudes are typically considered to be an evaluation, favourable or unfavourable, of an object, person or concept (Ajzen, 1991; Antonak \& Livneh, 2000). Attitudes have three main components: affective, cognitive, and behavioural (Fazio, 2007; Vilchinsky, Werner, \& Findler, 2010). As described by other authors in this field (e.g., Ajzen, 2002; Kruglanski et al., 2015), the affective component of an attitude refers to the positive or negative emotions evoked by an object, person, or concept. The cognitive component refers to an individual's thoughts, perceptions, beliefs, opinions, and mental conceptualisations of an object, person or concept. Finally, the behavioural component refers to the way in which an individual intends to, or does, act towards an object, person or concept. Attitudes differ in valence, or direction, reflecting positive, negative, or neutral evaluations (Ajzen, 2002). Attitudes also differ in strength, expressed by the degree of certainty or uncertainty of an individual's evaluation (Sheeran et al., 2016; Szymanski, Croft, \& Godor, 2018).

One area where attitude is important is physical education. There is emerging evidence to suggest that pupils who exhibit a more positive attitude toward physical activity in physical education are more likely to participate in physical activity outside of school (Bendíková \& Dobay, 2017; Portman, 2003). Additionally, active and well-motivated pupils are more likely to become active adults (Lonsdale et al., 2009; Telama, Yang, Laakso, \& Viikari, 1997). Also, pupils' feelings and emotions are among the numerous influences on their attitudes, engagement, and achievement in physical education, and these fluctuate according to contextual factors such as instructional content (Barr-Anderson et al., 2008; Sigmund, Frömel, Chmelík, Lokvencová, \& Groffik, 2009; Lodewyk \& Muir, 2017). For pupils who are deaf or hard of hearing emotional relationships in a regular school were studied by Kurková $(2009,2015)$. These pupils were found to have positive relationships to physical education, the response of pupils who are deaf or hard of hearing proved to be more emotional compared to classmates without disabilities. Regarding feelings, pupils who are deaf or hard of hearing showed negative emotional responses such as anxiety or stress. Pupils who are hard of hearing expressed concerns about misunderstandings in communication which caused them to respond with a delay to starting a new activity, and concerns about potential damage to hearing aids that might result from engagement in contact sports during physical education classes.

The objective of this study was to analyse differences in pupils' attitudes by gender in the second stage of primary schools for the deaf or hard of hearing in physical education classes.

\section{Methods}

\section{Participants}

The research and data collection were carried out in April and May 2017 among pupils who are deaf or hard of hearing in the second stage of primary schools for the deaf or hard of hearing at the national level. It was a targeted sample where participants were selected for the research sample according to the degree of hearing loss. An associated disability was an exclusion criterion. This information was verified in an interview with the class tutor or a representative of a special-education centre.

Of the total number of thirteen schools for the deaf or hard of hearing in the Czech Republic, six primary schools for the deaf or hard of hearing (Brno, Olomouc, Ostrava, Pilsen, Prague, Valašské Meziř́čí) agreed to participate in the research. A total of 86 pupils who are deaf or hard of hearing participated in the questionnaire survey (boys, $n=56 ; 65.1 \%$; girls, $n=30 ; 34.9 \%)$. The mean age and standard deviation was $14.3 \pm 1.4$ years, the age range was 11 to 17 years, and the median age was 14 years.

Within the sample, the majority of pupils have been deaf or hard of hearing from birth $(n=68 ; 79.1 \%)$. With respect to the severity of hearing impairment (hearing loss expressed in decibels), profound hearing loss including deafness $(n=51 ; 59.3 \%)$ is represented among the pupils. A compensation aid is used by most pupils $(n=62 ; 72.1 \%)$, in most cases a hearing aid ( $n=49 ; 79.0 \%$ ), fewer pupils have a cochlear implant $(n=13 ; 21.0 \%)$. For more information on the analysed sample, see Table 1.

\section{Data collection}

To implement the research, we used a non-standardised structured questionnaire (Antala et al., 2012). From this we compiled the final set of twenty-four questions in modified form. For pupils who are deaf or hard of hearing, when modifying the questionnaire, it was necessary to take into account their ability to concentrate, their fatigue and the comprehensibility of the various items. In the first phase, the questionnaire was consulted with three experts in the field of kinanthropology. The first stage of the questionnaire's verification was completed at a school for the deaf or hard of hearing. Based on 
Table 1

Sample demographic information

\begin{tabular}{|c|c|c|c|c|c|c|}
\hline & \multicolumn{2}{|c|}{ Boys $(n=56)$} & \multicolumn{2}{|c|}{ Girls $(n=30)$} & \multicolumn{2}{|c|}{ Total $(N=86)$} \\
\hline & $n$ & $\%$ & $n$ & $\%$ & $n$ & $\%$ \\
\hline \multicolumn{7}{|l|}{ Onset of disability } \\
\hline Since birth & 44 & 78.6 & 24 & 80.0 & 68 & 79.1 \\
\hline Since age 1 & 3 & 5.4 & 1 & 3.3 & 4 & 4.7 \\
\hline Since age 2 & 0 & 0.0 & 2 & 6.7 & 2 & 2.3 \\
\hline Since age 3 & 7 & 12.5 & 2 & 6.7 & 9 & 10.5 \\
\hline Since age 4 & 1 & 1.8 & 0 & 0.0 & 1 & 1.2 \\
\hline Since age 7 & 0 & 0.0 & 1 & 3.3 & 1 & 1.2 \\
\hline Since age 8 & 1 & 1.8 & 0 & 0.0 & 1 & 1.2 \\
\hline \multicolumn{7}{|l|}{ Degree of hearing loss } \\
\hline Mild & 8 & 14.3 & 2 & 6.7 & 10 & 11.6 \\
\hline Moderate & 13 & 23.2 & 12 & 40.0 & 25 & 29.1 \\
\hline Severe & 15 & 26.8 & 5 & 16.7 & 20 & 23.3 \\
\hline Profound including deafness & 20 & 35.7 & 11 & 36.7 & 31 & 36.0 \\
\hline \multicolumn{7}{|l|}{ Disability aid usage } \\
\hline Yes & 38 & 67.9 & 24 & 80.0 & 62 & 72.1 \\
\hline No & 18 & 32.1 & 6 & 20.0 & 24 & 27.9 \\
\hline \multicolumn{7}{|l|}{ Type of disability aid } \\
\hline Hearing aid & 28 & 73.7 & 21 & 87.5 & 49 & 79.0 \\
\hline Cochlear implant & 10 & 26.3 & 3 & 12.5 & 13 & 21.0 \\
\hline \multicolumn{7}{|l|}{ Communication } \\
\hline Czech sign language & 11 & 19.6 & 5 & 16.7 & 16 & 18.6 \\
\hline Czech language & 11 & 19.6 & 8 & 26.7 & 19 & 22.1 \\
\hline Combination & 34 & 60.7 & 17 & 56.7 & 51 & 59.3 \\
\hline
\end{tabular}

feedback and comments from pupils who are deaf or hard of hearing and their teachers, the various items of the questionnaire were adjusted. In collaboration with the Support Centre for Students with Special Needs at the Faculty of Education, Palacký University Olomouc, the assorted items of the questionnaire were consulted with and subsequently revised by three experts in the field of deaf education with an emphasis on the Czech sign language and the written form of the Czech language understandable to individuals who are deaf or hard of hearing. An adapted text version of the questionnaire in the Czech language was developed, taking into account the language competencies of pupils who are deaf or hard of hearing. In addition, a version in the Czech sign language was created.

Prior to the start of the actual survey, the purpose of the questionnaire was explained to the pupils and through their legal representatives - consent with their participation in the study was obtained in advance. Subsequently, the researcher explained how to answer the questions (including the pitfalls concerning potential ambiguities in answers to questions listed in the reverse order - e.g. The difficulty/easiness of physical education as a school subject). The survey was carried out using the distinct items of the questionnaire one by one in order to make sure pupils understood the respective questions. While completing the questionnaire, pupils were able to immediately consult any doubts they might have. The research had been approved by the Ethics Committee of the Faculty of Education, Palacký University Olomouc (ref. no. 1/2016).

The pupils completed the questionnaire in the presence of the class tutor and the researcher. Pupils who are deaf or hard of hearing completed the questionnaire in printed form and, in addition, they had access to a video of each question in the Czech sign language. If necessary, a teacher, an interpreter from/to sign language was available to pupils in order to avoid any misunderstanding of the questions.

In this study, we compare six scale questions concerning the attitudes of pupils who are deaf or hard of hearing in physical education classes. Those questions 
were related to attitudes towards physical education classes and assessed:

a) the popularity of physical education (Question 1: For me, physical education as a school subject is: very popular; popular; neither popular nor unpopular; unpopular; very unpopular);

b) the importance of physical education (Question 2: For me, physical education as a school subject is: very important; important; neither important nor unimportant; less important; unimportant);

c) the difficulty of physical education (Question 3: For me, physical education as a school subject is: very demanding; demanding; neither demanding nor easy; easy; very easy);

d) effort in physical education classes (Question 4: In physical education classes: I am: very assiduous; assiduous; sometimes assiduous, sometimes not; less assiduous; not assiduous at all);

e) emotionality in physical education classes (Question 5: In physical education classes I feel: always good; mostly good; sometimes good, sometimes bad; mostly bad; always bad);

f) emotional response if a physical education class is cancelled (Question 6: If a physical education class is cancelled: I am always happy, I am often happy, I am indifferent about it, I usually get upset, I always get upset).

For scale questions (1 to 6), pupils gave only one reply ( 1 was the highest level and 5 was the lowest level). The lower the average value of the replies, the physical education is for pupils more popular, more important, and more demanding, pupils are more assiduous, and they have better feeling during physical education classes or express the lower level of emotional response if a physical education class is cancelled.

\section{Data analysis}

The programme IBM SPSS Statistics (Version 23.0; IBM, Armonk, NY, USA) was used for data processing. The data were described using absolute and relative frequencies, including the mean and standard deviation. The non-parametric Mann-Whitney $U$-test was used to assess differences between two independent groups (boys versus girls). All tests were performed at a level of $\alpha=.05$. In addition, effect size coefficient was used (Cohen, 1988). The $Z$ value can be used to calculate an effect size, such as the $r$ proposed by Cohen (1988) where values $r=.50, .30$, and .10 may be interpreted as large, medium and small effects (Coolican, 2009).

For scale questions 1 to 6 , reliability in terms of internal consistency was verified using Cronbach's alpha. For questions 3 and 6, the scales of answers (numerical values) were reversed to provide measurement in the same sense as the other questions (due to the calculation of Cronbach's alpha, for any other processing they were left unchanged). While the $\alpha$ value $=.646$ is relatively low, it is still an acceptable value. In order for a questionnaire to be used for scientific investigation, it is recommended that alpha be greater than .70. The lower alpha value in our research is probably due to the small number of questions. It is a known fact that the value of Cronbach's alpha is dependent on the number of questions in the questionnaire. The more questions the higher the alpha value (Bland \& Altman, 1997).

\section{Results}

Table 2 and Table 3 present the intergroup comparison of pupils in physical education classes by gender. Both boys and girls consider physical education classes to be very popular or popular (boys 61\%, girls 63\%). Also, they evaluate physical education as very important or important (boys $75 \%$, girls $67 \%$ ). In the question concerning the demandingness of physical education, more than a third of boys and girls rate physical education as easy or very easy (boys $38 \%$, girls $37 \%$ ). In the Effort indicator, it was statistically proven $(p=.041)$ that boys make more effort towards physical education classes than girls (boys 38\%, girls 10\%). The statistical significance in this indicator was also confirmed by small effect size coefficient $(\operatorname{abs}(r)=.221)$. In the Emotionality 1 indicator, both boys and girls stated that physical education makes them feel always good or mostly good (boys $66 \%$, girls $83 \%$ ). In the Emotionality 2 indicator, when a physical education class is cancelled, half of the boys and most of the girls do not care (boys 50\%, girls 60\%). In the Emotionality 1 and 2 indicators, a small effect size coefficient $(\operatorname{abs}(r)=.127$ and $\operatorname{abs}(r)=.137$ ) was found, however statistical significance was not proven.

\section{Discussion}

With respect to the popularity of physical education, it is clear that both girls and boys consider physical education a favourite subject and none of them view physical education as being outright negative. In terms of gender, the attitude of pupils who are deaf or hard of hearing does not differ in this indicator.

In the Czech study by Hrabal and Pavelková (2010) the average value was lower in the indicator and Czech pupils from regular schools considered physical education to be more popular than our pupils. In a comparison by gender, Slovak boys rated physical education as more popular. Similar attitudes were found in Slovak 
Table 2

Intergroup comparison of absolute and relative frequencies of pupils attitudes towards physical education by gender

\begin{tabular}{|c|c|c|c|c|c|c|}
\hline & \multicolumn{2}{|c|}{ Boys $(n=56)$} & \multicolumn{2}{|c|}{ Girls $(n=30)$} & \multicolumn{2}{|c|}{ Total $(N=86)$} \\
\hline & $n$ & $\%$ & $n$ & $\%$ & $n$ & $\%$ \\
\hline \multicolumn{7}{|l|}{ Popularity } \\
\hline Very popular & 23 & 41.1 & 11 & 36.7 & 34 & 39.5 \\
\hline Popular & 11 & 19.6 & 8 & 26.7 & 19 & 22.1 \\
\hline Neither popular nor unpopular & 21 & 37.5 & 11 & 36.7 & 32 & 37.2 \\
\hline Unpopular & 1 & 1.8 & 0 & 0.0 & 1 & 1.2 \\
\hline \multicolumn{7}{|l|}{ Importance } \\
\hline Very important & 21 & 37.5 & 9 & 30.0 & 30 & 34.9 \\
\hline Important & 21 & 37.5 & 11 & 36.7 & 32 & 37.2 \\
\hline Neither important nor unimportant & 9 & 16.1 & 7 & 23.3 & 16 & 18.6 \\
\hline Less important & 5 & 8.9 & 3 & 10.0 & 8 & 9.3 \\
\hline \multicolumn{7}{|l|}{ Demandingness } \\
\hline Very demanding & 0 & 0.0 & 3 & 10.0 & 3 & 3.5 \\
\hline Demanding & 13 & 23.2 & 2 & 6.7 & 15 & 17.4 \\
\hline Neither demanding nor easy & 22 & 39.3 & 14 & 46.7 & 36 & 41.9 \\
\hline Easy & 13 & 23.2 & 10 & 33.3 & 23 & 26.7 \\
\hline Very easy & 8 & 14.3 & 1 & 3.3 & 9 & 10.5 \\
\hline \multicolumn{7}{|l|}{ Effort } \\
\hline Very assiduous & 21 & 37.5 & 3 & 10.0 & 24 & 27.9 \\
\hline Assiduous & 22 & 39.3 & 18 & 60.0 & 40 & 46.5 \\
\hline Sometimes assiduous, sometimes not & 11 & 19.6 & 8 & 26.7 & 19 & 22.1 \\
\hline Less assiduous & 2 & 3.6 & 1 & 3.3 & 3 & 3.5 \\
\hline \multicolumn{7}{|l|}{ Emotionality 1} \\
\hline Always good & 17 & 30.4 & 10 & 33.3 & 27 & 31.4 \\
\hline Mostly good & 20 & 35.7 & 15 & 50.0 & 35 & 40.7 \\
\hline Sometimes good, sometimes bad & 17 & 30.4 & 5 & 16.7 & 22 & 25.6 \\
\hline Mostly bad & 2 & 3.6 & 0 & 0.0 & 2 & 2.3 \\
\hline \multicolumn{7}{|l|}{ Emotionality 2} \\
\hline I am always happy & 4 & 7.1 & 3 & 10.0 & 7 & 8.1 \\
\hline I am often happy & 10 & 17.9 & 6 & 20.0 & 16 & 18.6 \\
\hline I am indifferent about it & 28 & 50.0 & 18 & 60.0 & 46 & 53.5 \\
\hline I usually get upset & 10 & 17.9 & 2 & 6.7 & 12 & 14.0 \\
\hline I always get upset & 4 & 7.1 & 1 & 3.3 & 5 & 5.8 \\
\hline
\end{tabular}

Table 3

Intergroup comparison of mean values of attitudes towards physical education by gender

\begin{tabular}{|c|c|c|c|c|c|c|c|}
\hline & \multicolumn{2}{|c|}{ Boys $(n=56)$} & \multicolumn{2}{|c|}{ Girls $(n=30)$} & \multirow[b]{2}{*}{$Z$} & \multirow[b]{2}{*}{$p$} & \multirow[b]{2}{*}{$\operatorname{abs}(r)$} \\
\hline & $M \pm S D$ & $95 \% \mathrm{CI}$ & $M \pm S D$ & $95 \% \mathrm{CI}$ & & & \\
\hline Popularity & $2.00 \pm 0.93$ & {$[1.75,2.25]$} & $2.00 \pm 0.87$ & {$[1.67,2.33]$} & -0.039 & .969 & .004 \\
\hline Importance & $1.96 \pm 0.95$ & {$[1.71,2.22]$} & $2.13 \pm 0.97$ & {$[1.77,2.50]$} & -0.831 & .406 & .090 \\
\hline Demandingness & $3.29 \pm 0.99$ & {$[3.02,3.55]$} & $3.13 \pm 0.97$ & {$[2.77,3.50]$} & -0.229 & .819 & .025 \\
\hline Effort & $1.89 \pm 0.85$ & {$[1.67,2.12]$} & $2.23 \pm 0.68$ & {$[1.98,2.49]$} & -2.048 & .041 & $.221 \dagger$ \\
\hline Emotionality 1 & $2.07 \pm 0.87$ & {$[1.84,2.30]$} & $1.83 \pm 0.69$ & {$[1.57,2.09]$} & -1.180 & .238 & $.127 \dagger$ \\
\hline Emotionality 2 & $3.00 \pm 0.97$ & {$[2.74,3.26]$} & $2.73 \pm 0.89$ & {$[2.41,3.06]$} & -1.268 & .205 & $.137 \dagger$ \\
\hline
\end{tabular}

Note. $\quad Z=$ Mann-Whitney $U$-test statistics; $p=$ statistical significance $(p$-values $<.05$ are highlighted in bold); abs $(r)=$ absolute value of Cohen's $r . \quad \dagger$ small effect size. 
pupils without disabilities (Antala et al., 2012), where these pupils showed similar mean values within the total sample. However, in a comparison of the mean values of responses of our pupils who are deaf or hard of hearing with Slovak pupils with sensory disabilities in special education (Kurková, Nemček, \& Labudová, 2015), pupils with sensory disabilities considered physical education to be more popular than pupils who are deaf or hard of hearing. A study carried out by Vašíčková (2016) confirmed a statistically significant difference in the overall rating of the attitude of regular pupils towards physical education as a teaching unit, given the popularity of the subject with both boys and girls. Pupils who considered physical education a popular school subject showed a higher degree of physical activity - expressed as the number of steps - and a more positive attitude to implementing physical education (Vašičcková, Neuls, \& Svozil, 2015).

In the Importance indicator, boys consider physical education to be more important as a school subject than girls. Similar differences related to gender were found in a study of Slovak pupils in regular primary schools (Antala et al., 2012), where boys rated the subject as more important. However, unlike in our study, this difference was statistically proven for Slovak pupils.

In a comparison of the overall sample in our study with the results of the other study of regular pupils or pupils with disabilities or orphan pupils (Antala et al., 2012; Bendíková \& Nemček, 2017; Hrabal \& Pavelková, 2010; Nemček \& Bergendiová, 2013), our pupils who are deaf or hard of hearing achieved lower mean values, which means that our pupils rate physical education as more important. The reason for this difference is fact that the advantage of these schools is a good didactic quality of teaching, which is adequate to the pupils' abilities (Kurková et al., 2010). Additionally, another advantage may also be the very good organisation of free time in these facilities, with an accent on the specific aspects of communication within this minority population (Kurková \& Scheetz, 2016; Kurková et al., 2010). Other possible explanation for this finding may be changes in pupil's physical activity interest (Bernstein, Phillips, \& Silverman, 2011).

Most pupils who are deaf or hard of hearing consider physical education to be an easy subject, but girls find it more demanding than boys. Similar results were found in Slovak pupils of regular primary school (Antala et al., 2012), where girls achieved lower mean values compared to Slovak boys, meaning that they consider physical education a demanding subject. In our comparison of the mean values for the total sample in the Difficulty indicator, differences were found in that pupils in our study considered physical education to be more demanding than pupils from Czech and
Slovak regular schools or schools with special educational settings (Antala et al., 2012; Hrabal \& Pavelková, 2010; Kurková et al., 2015).

In physical education classes, statistically significant differences were found in the Effort indicator, with boys making more effort in physical education classes than girls. Statistically significant differences were also confirmed in the Slovak study of regular pupils (Antala et al., 2012), where boys made more effort than girls. In a comparison of the majority population of Czech and Slovak primary school pupils (Antala et al, 2012; Hrabal \& Pavelková, 2010), the mean values of our total sample do not differ. The differences in the effort made by pupils who are deaf or hard of hearing in physical education classes may have been affected by the activities that are currently being done. In individuals who are deaf or hard of hearing, participation in physical activities may also be affected by climate change, fear of injury, current health condition or, if relevant, being overweight (Ellis, Lieberman, \& Dummer, 2014; Jaarsma, Dekker, Koopmans, Dijkstra, \& Geertzen, 2014; Telama, 2009; Tsai \& Fung, 2005). However, those factors in our study were not examined.

A gender comparison of differences in the feelings of pupils who are deaf or hard of hearing in physical education classes (Emotionality 1) shows a slight difference in that girls feel better in physical education classes compared to boys. In other studies, the authors came to the opposite conclusion (Antala et al., 2012; Görner \& Starší, 2001; Kurková, 2010, 2015). A comparison of the total sample of our study with the Slovak study of pupils with sensory disabilities or Slovak orphanages (Bendíková \& Nemček, 2017; Kurková et al., 2015) shows minimal differences. Our results also confirmed Cyprian study (Constantinides \& Silverman, 2018), where the positive attitude in physical education in the domain enjoyment and perceived usefulness for boys and girls in Cypriot pupils were found.

In the Emotionality 2 indicator, which determines pupils' attitudes in the event a physical education class is cancelled, no differences between boys and girls were found in the mean values. A comparison of the total sample of our study with the Slovak study of pupils with sensory disabilities (Kurková et al., 2015) also shows minimal differences. Both boys' and girls' neutral attitudes to the cancellation of physical education may be attributable to the fact that, with increasing age, the joy of movement and interest in physical activity decline (Constantinides \& Silverman, 2018; Phillips \& Silverman, 2015; Sigmund et al., 2018), which is - in turn - reflected in other areas of life of adults who are deaf or hard of hearing (Nemček, 2017). 


\section{Limits of study}

The results are valid for the given type of school, educational environment including educational programme, staff composition including managerial staff, teachers, educators, trainers. In our opinion, the impossibility of obtaining a comparable sample of pupils who are deaf or hard of hearing and who are educated in the educational mainstream poses an additional limitation.

\section{Conclusion}

In the present study, we have compared the differences by gender in the various indicators for physical education classes among pupils who are deaf or hard of hearing. In physical education classes, statistically significant differences were found in the Effort indicator, with boys making more effort in physical education classes than girls. However, given the size of the sample of pupils who are deaf or hard of hearing that was studied, the results cannot be generalised. For future research it might be interesting to find out if differences by gender in pupils who are deaf or hard of hearing can be attributed to cultural beliefs that are instilled in children from infancy.

\section{Acknowledgments}

The author wish to thank all the study participants for their time in completing questionnaires and the Support Centre for Students with Special Needs at the Faculty of Education, Palacký University Olomouc for their excellent collaboration.

\section{Conflict of interest}

There were no conflicts of interest.

\section{References}

Ajzen, I. (1991). The theory of planned behavior. Organizational Behavior and Human Decision Processes, 5, 179-211.

Ajzen, I. (2002). Perceived behavioral control, self-efficacy, locus of control, and the theory of planned behavior. Journal of Applied Social Psychology, 32, 665-683.

Antala, B., Šimonek, J., Čilík, I., Labudová, J., Medeková, H., Bebčáková, V., ... Melek, P. (2012). Telesná a športová výchova $v$ názoroch žiakov základných a stredných škôl [Physical and sports education as reflected in opinions of pupils of the elementary and secondary schools]. Bratislava, Slovakia: End.
Antonak, R. F., \& Livneh, H. (1988). The measurement of attitudes toward people with disabilities: Methods, psychometrics and scales. Springfield, IL: C. C. Thomas.

Antonak, R. F., \&. Livneh, H. (2000). Measurement of attitudes towards persons with disabilities. Disability and Rehabilitation, 22, 211-224.

Barr-Anderson, D. J., Neumark-Sztainer, D., Schmitz, K. H., Ward, D. S., Conway, T. L., Pratt, C., ... Pate, R. R. (2008). But I like PE: Factors associated with enjoyment of physical education class in middle school girls. Research Quarterly for Exercise and Sport, 79, 18-27.

Bendíková, E., \& Dobay, B. (2017). Physical and sport education as a tool for development of a positive attitude toward health and physical activity in adulthood. European Journal of Contemporary Education, 6, 14-21.

Bendíková, E., \& Nemček, D. (2017). Attitudes and preferences of children living in orphanage towards physical education lessons. European Journal of Contemporary Education, 6, 664-673.

Bernstein, E., Phillips, S., \& Silverman, S. (2011). Attitudes and perceptions of middle school students toward competitive activities in physical education. Journal of Teaching in Physical Education, 30, 69-83.

Bland, J. M., \& Altman, D. G. (1997). Statistics notes: Cronbach's alpha. British Medical Journal, 314(7080), 572.

Cohen, J. (1988). Statistical power analysis for the behavioral sciences (2nd ed.). New York, NY: Lawrence Erlbaum Associates.

Constantinides, P., \& Silverman, S. (2018). Cypriot urban elementary students' attitude toward physical education. Journal of Teaching in Physical Education, 37, 69-77.

Coolican, H. (2009). Research methods and statistics in psychology. London, United Kingdom: Hodder.

Ellis, M. K., Lieberman, L. J., \& Dummer, G. M. (2014). Parent influences on physical activity participation and physical fitness of deaf children. Journal of Deaf Studies and Deaf Education, 19, 270-281.

Fazio, R. H. (2007). Attitudes as object-evaluation associations of varying strength. Social Cognition, 25, 603-637.

Görner, K., \& Starší, J. (2001). Postoje, vedomosti a názory žiakov na II. stupni základnej školy na telesnú výchovu [Attitudes, knowledge and opinions of older elementary students]. Banská Bystrica, Slovakia: Matej Bel University.

Hrabal, V., \& Pavelková, I. (2010). Jaký jsem učitel [What type of teacher I am]. Prague, Czech Republic: Portál.

Jaarsma, E. A., Dekker, R., Koopmans, S. A., Dijkstra, P. U., \& Geertzen, J. H. B. (2014). Barriers to and facilitators of sports participation in people with visual impairments. Adapted Physical Activity Quarterly, 31, 240-264.

Kruglanski, A. W., Jasko, K., Chernikova, M., Milyavsky, M., Babush, M., Baldner, C., \& Pierro, A. (2015). The rocky road from attitudes to behaviors: Charting the goal systemic course of actions. Psychological Review, 122, 598-620.

Kurková, P. (2009). Dimenze emočních reakcí v tělesné výchově u žáků se sluchovým postižením v prostř̌edí běžné školy [Dimension of emotional reactions in the physical education in pupils who are deaf or hard of hearing in regular school settings]. Česká kinantropologie, 13(4), 40-49. 
Kurková, P. (2015). Emotions in the physical activities of Czech students who are deaf or hard of hearing in general and special education. Journal of Physical Education and Sport, 15, 823-828.

Kurková, P., Nemček, D., \& Labudová, J. (2015). Pupils with sensory disabilities in physical education lessons: Attitudes and preferences. Acta Gymnica, 45, 139-145.

Kurková, P., \& Scheetz, N. A. (2016). Communication strategies used by physical education teachers and coaches in residential schools for the deaf in the U.S. Acta Facultatis Educationis Physicae Universitatis Comenianae, 56, 1-16.

Kurková, P., Scheetz, N. A., \& Stelzer, J. (2010). Health and physical education as an important part of school curricula: A comparison of schools for the deaf in the Czech Republic and the United States. American Annals of the Deaf, 155, 78-87.

Lodewyk, K. R., \& Muir, A. (2017). High school females' emotions, self-efficacy, and attributions during soccer and fitness testing in physical education. Physical Educator, 74, 269-295.

Lonsdale, C., Sabiston, C. M., Raedeke, T. D., Ha, A. S. C., \& Sum, R. K. W. (2009). Self-determined motivation and students' physical activity during structured physical education lessons and free choice periods. Preventive Medicine, $48,63-79$.

Ministry of Education, Youth and Sports of the Czech Republic. (2016). Rámcový vzdělávací program pro základní vzdělávání (třetí verze) [Framework Education Programme for Basic Education (with amendments as at January $1^{\text {st }}$ 2016)]. Retrieved from http://www.nuv.cz/uploads/RVP ZV_2016.pdf

Nemček, D. (2017). Self-esteem analyses in people who are deaf or hard of hearing: A comparison between active and inactive individuals. Physical Activity Review, 5, 95-104.

Nemček, D., \& Bergendiová, F. (2013). Oblúbenost’ telesnej výchovy žiakov s telesným postihnutím [Popularity of physical education among pupils with physical disabilities]. Telesná výchova a šport, 23(2), 2-6.

Phillips, S. R., \& Silverman, S. (2015). Upper elementary school student attitudes toward physical education. Journal of Teaching in Physical Education, 34, 461-473.

Portman, P. A. (2003). Are physical education classes encouraging students to be physically active? Experience of ninth graders in their last semester of required physical education. Physical Educator, 60, 150-160.

Scheetz, N. A. (2012). Deaf education in the 21st century: Topics and trends. Boston, MA: Pearson.
Sheeran, P., Maki, A., Montanaro, E., Avishai-Yitshak, A., Bryan, A., Klein, W. P., ... Rothman, A. J. (2016). The impact of changing attitudes, norms, and self-efficacy on health-related intentions and behavior: A meta-analysis. Health Psychology, 35, 1178-1188.

Sigmund, E., Badura, P., Sigmundová, D., Voráčová, J., Zacpal, J., Kalman, M., ... Hamrik, Z. (2018). Trends and correlates of overweight/obesity in Czech adolescents in relation to family socioeconomic status over a 12-year study period (2002-2014). BMC Public Health, 18, 122.

Sigmund, E., Frömel, K., Chmelík, F., Lokvencová, P., \& Groffik, D. (2009). Oblíbený obsah vyučovacích jednotek tělesné výchovy - pozitivně hodnocený prostředek vyššího tělesného zatižení děvčat [Preferred contents in the physical education lessons - positively evaluated means of increasing physical load of females]. Tělesná kultura, 32(2), 45-63.

Szymanski, A., Croft, L., \& Godor, B. (2018). Determining attitudes toward ability: A new tool for new understanding. Journal of Advanced Academics, 29, 29-55.

Telama, R. (2009). Tracking of physical activity from childhood to adulthood: A review. Obesity Facts, 2, 187-195.

Telama, R., Yang, X., Laakso, L., \& Viikari, J. (1997). Physical activity in childhood adolescence as predictor of physical activity in young adulthood. American Journal of Preventive Medicine, 13, 317-323.

Tsai, E., \& Fung, L. (2005). Perceived constraints to leisure time physical activity participation of students with hearing impairment. Therapeutic Recreation Journal, 39, 192-206.

Vašíčková, J. (2016). Pohybová gramotnost v České republice [Physical literacy in the Czech Republic]. Olomouc, Czech Republic: Palacký University Olomouc.

Vašíčková, J., Neuls, F., \& Svozil, Z. (2015). Popularity of school physical education and its effect on performed number of steps. Journal of Physical Education and Sport, $15,40-46$.

Vilchinsky, N., Werner, S., \& Findler, L. (2010). Gender and attitudes toward people using wheelchairs: A multidimensional perspective. Rehabilitation Counseling Bulletin, 53, 163-174.

Zákon č. 561/2004 Sb., o předškolním, základním středním, vyšším odborném a jiném vzdělávání (školský zákon) [Act No 561/2004 Coll., on preschool, primary, secondary, tertiary vocational and other education (the Education Act)]. (2004). 